\title{
The Role Of School Conselors In Advocacy Services
}

\author{
Rio Hermawan ${ }^{\mathrm{a}}$, Roni Pransiska ${ }^{\mathrm{b}}$ \\ ${ }^{a}$ Vocational High School 3 Kasihan \\ ${ }^{\mathrm{b}}$ Vocational High School 2 Pangandaran \\ e-mail: riohermawan1990@gmail.com ${ }^{\mathrm{a}}$
}

\begin{abstract}
The main role of School Counselors in the Era of the Indonesian Revolution 4.0, is expected to formulate various types of counseling guidance services that are appropriate to the needs of students in this era. One type of school counselor services in providing services to students needed in this era is an advocacy service that refers to Permendikbud No. 111 (2014) although in this regulation we only get very limited information about advocacy, but it is expected that in its implementation, school counselors will be able to interpret and carry out advocacy at the micro and macro levels. Counselors should be able to: (1) empower students by helping them develop advocacy skills, (2) conduct relevant negotiation efforts to help students access resources, (3) build collaborative relationships with relevant community institutions to overcome various challenges, (4) implementing advocacy ideas at the system level, (5) communicating relevant information to the public, and (6) engaging in social / political advocacy activities. Advocacy services are counselor services in schools that are intended to assist students who experience non-educational, discriminatory, malpractice, violence, harassment, and criminal behavior. The function of counselor services in advocacy services, helps students gain learning about their rights and / or interests that are not getting much attention. Therefore, the role of counselors in advocacy services is very important in the process of counseling guidance services in schools. So the counselor must have the ability to guide students well. In order for counselors to be able to provide optimal guidance services to students, the counselor must be able to understand the characteristics of the counselee.
\end{abstract}

\section{Keywords: Industrial Revolution 4.0, School Counselors, Advocacy Services}

\begin{abstract}
Abstrak: Peran utama Konselor Sekolah di Era Revolusi Indutri 4.0, diharapkan dapat merumuskan berbagai jenis layanan bimbingan konseling yang sesuai dengan kenbutuhan siswa pada era ini. Salah satu jenis layanan konselor sekolah dalam memberikan pelayanan kepada peserta didik yang dibutuhkan pada era ini adalah layanan advokasi yang mengacu pada Permendikbud No. 111 (2014) meski dalam permen ini kita hanya mendapatkan informasi yang amat terbatas tentang advokasi, tetapi diharapkan dalam implementasinya, Konselor sekolah mampu memaknai dan melaksanakan advokasi pada tataran mikro maupun makro. Konselor seyogyanya mampu: (1) memberdayakan peserta didik dengan membantu mereka membangun keterampilan advokasi, (2) melakukan upaya negosiasi yang relevan guna membantu peserta didik mengakses sumber daya, (3) membangun hubungan kolaboratif dengan lembaga masyarakat yang relevan guna mengatasi berbagai tantangan, (4) melaksanakan gagasan advokasi pada level sistem, (5) mengkomunikasikan informasi yang relevan kepada publik, dan (6) melibatkan diri dalam kegiatan advokasi sosial/politik. Layanan advokasi adalah layanan konselor di sekolah yang dimaksudkan untuk memberi pendampingan peserta didik yang mengalami perlakuan tidak mendidik, diskriminatif, malpraktik, kekerasan, pelecehan, dan tindak kriminal. Fungsi Layanan konselor dalam layanan advokasi, membantu peserta didik memperoleh pembelajaran atas hak dan atau kepentingannya yang kurang mendapat perhatian. Oleh karena itu, peran konselor dalam layanan advokasi sangat penting dalam proses layanan bimbingan konseling di sekolah. Sehingga konselor harus mempunyai kemampuan untuk membimbing peserta didik dengan baik. Agar konselor mampu memberi pelayanan bimbingan secara optimal kepada peserta didik maka konselor harus mampu memahami karakteristik konseli.
\end{abstract}

Kata Kunci: Revolusi Industri 4.0, Konselor Sekolah, Layanan Advokasi

DOI : https://dx.doi.org/ 10.26486/ijagc.v1i1.1046

URL : http://ejurnal.mercubuana-yogya.ac.id/index.php/IJAGC/index

Email : ijagc@mercubuana-yogya.ac.id 


\section{INTRODUCTION}

The main role of School Counselors in the Era of the industrial revolution 4.0, is expected to be able to formulate various types of counseling guidance services that fit the needs of students in this era. The role of school counselors is needed in the era of the industrial revolution 4.0 as it is now where students in this generation need to be supervised as well as guidance. The school counselor / school counselor is expected to adjust the school counselor's service activities with changes / challenges and needs in this era. ASCA (The American School Counselor Association) in 2003 (Britzman, 2005) through a model created by "A Framework for School Counseling Programs" which aims to support school counselors provide services directly to each student and take a role in leading to produce a system in making changes in school.

Counselors play an important role in the education system and they are considered as school psychologists. Counselors act as problem solving students. Guidance and counseling services in schools is an effort to help students in the development of personal life, social life, learning activities, and career planning and development. This service also helps overcome weaknesses and obstacles as well as problems faced by students.

Referring to the Minister of Education and Culture Regulation (Permendikbud) number 111 (2014) which mentions categorized advocacy service activities in services outside the classroom. Advocacy services are broadening the four components of guidance and counseling services, namely basic services, specialization services and individual planning, responsive services and system support. Advocacy services can be carried out in each of the four components of guidance and counseling services. Permendikbud number 111 on guidance and counseling in primary and secondary education (2014) also explains advocacy services are services that help students or counselees in the form of advocating for the rights of counselees who experience discriminatory treatment, by providing assistance to students or counselees who experience treatment non-educating, discriminatory, malpractice, violence, harassment and crime. The function of counseling guidance services in advocacy services, helps students gain learning about their rights and / or interests that are not getting much attention.

The needs of student advocacy services can be met through a comprehensive school counselor program that includes efforts to facilitate student problem solving. While some students need counseling services that focus on special needs. An ideal comprehensive program for school professional counselors is supported by the support of a system of collaboration with the community and advocacy efforts.

Based on the formulation of the problems stated above, the purpose of this study is to obtain data and information on: 1) the nature of advocacy services in schools; 2) the nature of school counselors and 3) the role of school counselors in advocacy services. The purpose of this paper is to socialize the role of counselor advocacy in the counseling process at school.

\section{METHODS}

This article uses a descriptive analytic type, which describes the nature of advocacy services, the nature of school counselors, and the role of school counselors in advocacy services. The types of data used in this article are secondary data obtained from literature, books, journals, reports and the internet. Data collection techniques used are library studies (library research) by finding and collecting secondary data sourced from various references both books, journals, and the internet, for which validity can be justified. The analysis technique used in this article is a content analysis method that is by explaining and analyzing from existing sources, after which various references are linked. 


\section{Character Of The Nature Of Advocacy Services}

According to Toporek (2000), advocacy consists of several aspects of empowering individuals or groups by helping, recognizing, and overcoming social and political barriers to welfare, in the form of actions in the form of social action. Meanwhile, according to Prayitno, et al. (2014: 150). An advocacy service is a counseling service that helps students to regain their rights that are not heeded and or get wrong treatment in accordance with the demands of a smart and praiseworthy character.

Besides according to Toporek and Prayitno advocacy services in this paper also refer to the Ministry of Education and Culture. (2016: 23) Advocacy is a guidance and counseling service that is intended to provide assistance to students / counselees who experience treatment that is not educative, discriminatory, malpractice, violence, harassment, and crime.

The advocacy service is designed with 2 basic objectives: (a) enhancing personality and strength and (b) fostering environmental change (Lewis \& Bradley, 2000). Meanwhile According to ASCA, advocacy is a broad and diverse process. The ASCA National Model states, "Advocating for the academic success of every student is the role of school counselors and placing them as leaders in promoting school reform" (ASCA, 2003: 24). According to the ASCA National Model, advocacy efforts for school counselors are aimed at (a) removing barriers that hinder student development; (b) creating opportunities for learning for all students; (c) ensuring access to quality school curricula; (d) collaborating with others inside and outside the school to help students meet their needs, and (e) promote positive systemic change in school. Therefore, advocacy involves leadership, collaboration, and systemic change. In line with ASCA's opinion, According to Schiltz (2012) the purpose of advocacy is to represent the best interests of students in seeking support and educational services.

Based on the explanation and understanding of the objectives of advocacy services, it can be concluded that school advocacy services, namely GC (Guidance and Counseling) services, help students to obtain their rights and conduct relevant negotiation efforts to help students and provide assistance to students who experience discriminatory treatment, malpractice, violence, harassment and crime. The purpose of advocacy services is to remove obstacles that hinder student development, collaborate with others inside and outside of school to help students meet their needs, representing the best interests of students in seeking support and educational services. Therefore, advocacy involves leadership, collaboration, and systemic change.

\section{Private School Concelors In Indonesia}

In Indonesia, the counselor as one of the types of education personnel in the Law of the Republic of Indonesia Number 20 of 2003 concerning the National Education System Chapter I Article 1 Number 6 states that "educators are educational staff who are qualified as teachers, lecturers, counselors, tutors, instructors, tutors, instructors, facilitators, and other designations that are appropriate to their specificity, and participate in the administration of education ". (Ministry of National Education, 2008). Based on the alignment of these positions the role of the counselor has the same function in achieving national education goals. Nevertheless, the counselor has a duty and uniqueness in carrying out these functions.

Furthermore, in the Minister of National Education Regulation No. 27/2008 concerning Academic Qualification Standards and Counselor Competence, it is stated that "Counselors are professional educators who have completed undergraduate academic education (S-1) Guidance and Counseling study programs and Professional Counselor Education programs from universities high level of providers of accredited education personnel procurement programs. "While in the Republic of Indonesia Minister of Education and Culture Regulation No. 111 of 2014 concerning Guidance and Counseling in Primary and Secondary Education it is stated that" Counselors are professional educators with academic 
qualifications of at least Bachelor of Education (S-1) in the field of Guidance and Counseling and have passed the Professional Education of Guidance and Counseling / Counselor Teachers. "and" Guidance and Counseling Teachers are educators with minimum academic qualifications Bachelor of Education (S-1) in the field of Guidance and Counseling and have have competence in the area of Guidance and Counseling ".

Explicit recognition and alignment of positions between educators do not eliminate the sense that each teaching staff, including counselors, has a task context, performance expectations, and specific service settings that contain unique and differences. The characteristics of a counselor according to Hackney and Cormier (2009) suggested that (1) having self-awareness and understanding, (2) having good psychological health, (3) sensitive to race, ethnicity, and cultural factors of himself and others, (4 ) open, objective, competent, trustworthy and has good interpersonal. Based on Bordin (McLeod, 2003) mentions three elements in forming a good working relationship with the counselee, namely: the creation of an emotional bond between the two, reaching an agreement regarding the goals of counseling, and a shared understanding of the task to achieve counseling goals.

For this reason, counselors need to provide optimal and comprehensive counseling services according to students' needs by providing suitable GC programs such as organizing orientation services, information services, distribution placement services, content mastery services, individual counseling services, group guidance services, group counseling services, group services consultancy, mediation services and advocacy services (Prayitno, 2009). In line with Prayitno, according to Tohirin (2007) there are nine types of guidance and counseling services, namely "(1) orientation service; (2) information services; (3) placement / distribution services; (4) content mastery services; (5) individual counseling services; (6) group guidance services; (7) group counseling services; (8) consulting services; (9) mediation services. "According to Tohirin (2007) Counseling guidance services in advocacy services, helping students gain learning about their rights and / or interests that do not receive enough attention.

From the explanation above, the Counselor is a professional educator with a minimum academic qualification. Bachelor of Education (S-1) in the field of Guidance and Counseling and has passed the Professional Education of Guidance and Counseling / Counseling Teachers. " minimum Bachelor of Education (S-1) in the field of Guidance and Counseling and have competence in the field of Guidance and Counseling ". The characteristics of a counselor are (1) having self-awareness and understanding, (2) having good psychological health, (3) sensitive to race, ethnicity, and cultural factors of himself and others, (4) open, objective, competent, able trusted and has good interpersonal. As well as three elements that must be had by the counselor in the formation of a good working relationship with the counselee, namely: the creation of an emotional bond between the two, the achievement of an agreement regarding the goals of counseling, and mutual understanding of the task to achieve counseling goals.

Advocacy services in guidance and counseling are found in Basic services, namely anticipatory, preventive and development services. This service is intended for all students without exception. Basic services are directed to the development of development competencies in accordance with the stages and tasks of student development. This service can be carried out by the counselor himself or in collaboration with, subject teachers, parents, and experts outside the school. The form of services pursued include advocacy services and facilitation of the selection of family clusters / fields of interest through the process of counseling, consultation and other relevant services. Advocacy services are guidance and counseling / counseling services at schools that are intended to provide assistance to students I counselees who experience non-educative, discriminatory, malpractice, violence, harassment, and criminal behavior. The function of counseling guidance services in advocacy 
services, helps students gain learning about their rights and / or interests that are not getting much attention.

\section{The Role Of School Conselors In Advocacy Services}

Borders, L. D. (2002) states that school counselors are the forefront of mental health professionals for students and families. Sink further, C. A. (2002), explains that the development of the 21 st century is easy, encouraging school counselors to stay focused on advocating for themselves and their programs and creating a comfortable community at school. Meanwhile, according to Paisley \& McMahon, (2001), the task and role of counselors in schools is to provide advocacy for all students to improve their educational experience and learning outcomes at school.

Advocacy services in schools within the scope of guidance and counseling based on Permendikbud number 111 on guidance and counseling in primary education and secondary education (2014) also explains advocacy services are services that help students or counselees in the form of advocating for the rights of counselees who experience discriminatory treatment. , by giving assistance to students or counselees who experience un educative, discriminatory treatment, malpractice, violence, harassment and crime.

Counseling advocacy services in schools are in line with the counseling process. When counselors recognize external factors as obstacles to individual development, they can choose advocacy services in schools. The significant role of advocacy is needed by the counselee especially when individuals or groups lack access to the advocacy services they really need while at school. (Lewis, et.al, 2002)

In order to carry out the counselee's advocacy role effectively, the counselor must be able to:

1. Negotiate appropriate services and education systems on behalf of counselee / students

2. Helping counselees and students to get access to the resources they need.

3. Identify barriers to individual and group welfare

4. Build an initial plan that will be carried out to deal with obstacles.

5. Identify the overall potential for overcoming obstacles

6. Implement an action plan

Ideally, the counseling process can lead the counselee towards self-empowerment. Counselors help with the abilities they have and to speak on behalf of the counselee.

As according to Lewis (2002). Empowerment strategies that underline the orientation of advocacy include:

1. Identify student strengths and resources.

2. Identify social, political, economic, and cultural factors that influence students

3. Recognize signs that indicate individual behavior and attention reflect responses to systemic or internal oppression.

4. At the right level of development, helping individual students identify external barriers that affect development.

5. Bridging students in self advocacy skills.

6. Helping students develop self-advocacy action plans.

7. Assist students in implementing action plans.

School counselors should never feel that they have to choose between providing services and acting as a support for system change. The urge to engage in systemic change often stems from the counselor's desire to prevent this type of counselee problem. The American Advocacy of Competence Counseling Association suggests that changes to the system in schools must involve the following steps (Lewis, et.al. 2002):

1. Identify environmental factors that afflict student development. 
2. Provide and interpret data to show urgency for change

3. Work with other stakeholders, develop a vision to guide change.

4. Analyze the sources of political power and social influence in the system.

5. Develop a step by step plan for implementing the change process.

6. Recognize and deal with resistance.

7. Assess the effects of counselor's advocacy efforts on the system, and finally, on students.

Based on this the authors conclude that the role of the counselor in advocacy services in schools in order to carry out the counselee's advocacy role effectively, the counselor must be able to: (1) Negotiate an appropriate service and education system on behalf of the counselee / student, (2) Help the counselee and students to get access to the resources they need, (3) Identify obstacles to the well-being of individuals and groups, (4) Build an initial plan to deal with obstacles, (5) Identify the overall potential for dealing with obstacles.

Ideally, the counseling process can lead the counselee towards self-empowerment. Counselors help with the abilities they have and to speak on behalf of the counselee. The process of school counselors in advocacy services to students: (1) Engaging in negotiations relevant to the education system and services on behalf of students, (2) Students get assistance in advocacy services at school to the sources of access needed, (3) Identifying challenges to group welfare and individuals, (4) Identifying students to face challenges.

Even though Permendikbud No. 111 In 2014 we only got very limited information about advocacy, but it is hoped that in its implementation, GC / Counselor Teachers will be able to interpret and translate it further. In a sense, GC Teachers are able to carry out advocacy at the micro and macro level. GC / Counselor teachers should be able to: (1) empower learners (counselees) by helping them build advocacy skills, (2) make relevant negotiation efforts to help students (counselees) access resources, (3) build collaborative relationships with institutions relevant communities to overcome various challenges, (4) implementing advocacy ideas at the system level, (5) communicating relevant information to the public, and (6) engaging in social / political advocacy activities.

The success of GC / Counselor Teachers in carrying out advocacy, besides having an impact on welfare and justice for students and their environment, will also automatically help increase public confidence in the Guidance and Counseling and school services, towards the GC / Counselor Teacher profession as a whole and of course towards The GC / Counselor teacher concerned, that he is a professional.

\section{CONCLUSION}

The role of the counselor in advocacy services in schools in order to carry out the counselee's advocacy role effectively. Even though Permendikbud No. 111 In 2014 we only got very limited information about advocacy, but it is hoped that in its implementation, GC / Counselor Teachers will be able to interpret and translate it further. In a sense, GC Teachers are able to carry out advocacy at the micro and macro level. GC / Counselor teachers should be able to: (1) empower learners (counselees) by helping them build advocacy skills, (2) make relevant negotiation efforts to help students (counselees) access resources, (3) build collaborative relationships with institutions relevant communities to overcome various challenges, (4) implementing advocacy ideas at the system level, (5) communicating relevant information to the public, and (6) engaging in social / political advocacy activities.

In implementing advocacy services counselors must be able to: (1) Negotiate appropriate services and education systems on behalf of counselees / students, (2) Assist counselees and students to get access to the resources they need, (3) Identify barriers to the welfare of individuals and groups , (4) Building an initial plan that will be carried out to deal with obstacles, (5) Identifying the overall potential for dealing with obstacles. 


\section{REFERENCES}

American School Counselor Association. (2003). The ASCA national model: A framework for school counseling programs. Alexandria, VA: Author.

Borders, L. D. (2002). School counseling in the 21st century: Personal and professional reflections. Professional School Counseling, 5(3), 180. Retrieved From http://eresources.perpusnas.go.id.

Britzman, M. (2005). Improving our moral landscape via character education: An opportunity for school counselor leadership. Professional School Counseling. 293-295.

Depdiknas. (2008). Penataan pendidikan profesional konselor dan layanan bimbingan dan konseling dalam jalur pendidikan formal.

Hackney, H., \& Cormier, S. (2009). The professional counselor: A process guide to helping. 6th edition. Pearson.

Kementerian Pendidikan Dan Kebudayaan Republik Indonesia, (2016). Pedoman bimbingan dan konseling pada pendidikan dasar dan pendidikan menengah.

Schiltz, K.L (2012). The role of educational advocacy. Blog Psycologytoday.com. Dari: http://www.psychologytoday.com/intl/blog/beyond-the-label/201205/the-roleeducational-advocay.

Lewis, J. A. (2002). Working with adolescents: The cultural context. In J. Carlson \& J. Lewis (Eds.), Counseling the adolescent: Individual, family, and school interventions, 3-16. Love Publishing Company.

Lewis, J. A., Arnold, M. S., House, R., \& Toporek, R. (2002). American counseling association advocacy competencies. American Counseling Association.

Lewis, J., \& Bradley, I,. (Eds). (2000). Advocacy in counseling: Counselor, clients, and community. ERIC

McLeod, John. (2003). Pengantar konseling: Teori dan studi kasus. Terjemahan. Prenada Media Group, Jakarta.

Paisley, P. O., \& McMahon, H. G. (2001). School counseling for the 21st century: Challenges and opportunities. Professional School Counseling, 5(2), 106. Retrieved From http://e-resources.perpusnas.go.id.

Peraturan Menteri Pendidikan dan Kebudayaan Nomor 111 Tahun 2014 tentang Bimbingan dan konseling pada pendidikan dasar dan menengah. Jakarta: Depdikbud.

Prayitno, dkk. (2014). Pembelajaran melalui pelayanan BK di satuan pendidikan. FIP-UNP

Prayitno. (2009). Wawasan profesional konseling. UNP.

Tohirin. (2007). Bimbingan dan konseling di sekolah dan madrasah. PT Raja Grafindo Persada. 
Toporek, R.L. (2000). Developing a common language and framework for understanding advocacy in counseling. In J. Lewis \& L. bradley (Eds.), Advocacy in counseling: Counselors, clients, and community (5-14). Caps Publications.

Undang- Undang RI No.20 Tahun 2003 Tentang Sistem Pendidikan Nasional. 